\title{
Massive mortality of Prussian carp Carassius gibelio in the upper Elbe basin associated with herpesviral hematopoietic necrosis (CyHV-2)
}

\author{
Tomáš Daněk ${ }^{1}$, Lukáš Kalous ${ }^{1, *}$, Tomáš Vesely̆ ${ }^{2}$, Eva Krásová$^{1}$, Stanislava Reschová ${ }^{2}$, \\ Kateřina Rylková ${ }^{1}$, Pavel Kulich ${ }^{2}$, Miloslav Petrtýl ${ }^{1}$, Dagmar Pokorová ${ }^{2}$, Martin Knytl ${ }^{1}$ \\ ${ }^{1}$ Department of Zoology and Fisheries, Faculty of Agrobiology, Food and Natural Resources, \\ Czech University of Life Sciences Prague, 16521 Praha 6 - Suchdol, Czech Republic \\ ${ }^{2}$ Veterinary Research Institute, Hudcova 70, 62100 Brno, Czech Republic
}

\begin{abstract}
From 22 May to 10 June 2011 massive mortality of Prussian carp Carassius gibelio was observed in alluvial Lake Řehačka close to the Elbe River in the Czech Republic. More than $1400 \mathrm{~kg}$ of dead fish were collected and no other fish species were affected. Further molecular and cytogenetic investigation of fish $(n=232)$ revealed that the Rehačka population of Prussian carp consisted exclusively of gynogenetic triploid females. The causative agent was identified by means of molecular and electron microscopy as a herpesviral hematopoietic necrosis virus (Cyprinid herpesvirus 2, CyHV-2). This is the first report of CyHV-2 from the Czech Republic and the second finding worldwide of CyHV-2 causing mass mortality of C. gibelio. Some other localities in the upper Elbe River basin where C. gibelio was affected are also noted. We assume that the massive wave of deaths of all female gynogenetic Prussian carp can be attributed to limited genetic variation and the favourable conditions for development of viral disease.
\end{abstract}

KEY WORDS: Cypriniformes · Herpesvirus · Triploid · Gynogenetic · Mortality

\section{INTRODUCTION}

The triploid biotype of Prussian carp Carassius gibelio Bloch 1782 is considered the most successful non-native fish in Europe. It easily becomes one of the dominant species in newly inhabited areas, and it has a severe impact on the environment and aquaculture (Economidis et al. 2000, Varadi et al. 2000, Özcan 2007, Lusková et al. 2010, Savini et al. 2010). The type of reproduction significantly facilitates spreading of all-female populations due to rapid multiplication realized through sperm-dependent parthenogenesis.

When the eggs of Carassius gibelio are inseminated by males of other species, the heterologous sperm triggers development but does not contribute significantly to the formation of the zygote (Gui \& Zhou 2010). This is known as gynogenesis and it leads to all-female offspring, each of which is considered a clone of the mother (Lamatsch \& Stöck 2009).

The first record of the invasive triploid form of Carassius gibelio in the Czech Republic was in the lower stretches of the Dyje River (Lusk et al. 1977). The population was derived from a Danubian invasion (Holčík \& Žitňan 1978) and consisted exclusively of triploid gynogenetic females (Peňáz et al. 1979). Triploid Prussian carp subsequently invaded all 3 main hydrological systems of the Czech Republic (Lusk et al. 1980, 1998, Lusk 1986), and aquaculture activities were considered the key factor accounting for its spread (Slavík \& Bartoš 2004). In the Elbe River basin, an all-female population of C. gibelio was recorded for the first time in 1989 (Kubečka 1989) and later became a natural component of all suitable habitats (Halačka et al. 2003). In the early 1990s, the 
first males and diploids within the population of C. gibelio in the Dyje River alluvium (Danube basin) were found (Halačka et al. 2003, Lusková et al. 2004). In a relatively short time the former all-female triploid population changed to a diploid-polyploid complex with up to $43 \%$ males (Vetešník 2005). Similar situations were described in other European localities (Černý \& Sommer 1992, Abramenko et al. 1998, 2004, Tóth et al. 2005).

Certain localities are now represented either by all-female gynogenetic populations or by the concurrent occurrence of fish with different ploidy and various proportions of males. However, low genetic variability in introduced all-female populations of Prussian carp is expected due to the low number of initial founders combined with the gynogenetic type of reproduction (Hänfling 2007). The all-female clonal populations could also be classified as vulnerable, since antigen recognition and killing by T-cells is genetically restricted by the major histocompatibility complex (MHC) (Somamoto et al. 2009). Lower tolerance to parasites has been reported in gynogens (Lively et al. 1990, Moritz et al. 1991, Poulin et al. 2000, Hakoyama et al. 2001).

In the present paper we report the rapid, massive and selective mortality of thousands of morphologically and genetically identified Prussian carp from Lake Řehačka with further investigation of ploidy level and sex ratio of the Prussian carp and identification of the causative agent. The concurrent occurrence of a massive kill of Prussian carp at several other localities in the upper Elbe River basin is also noted.

\section{MATERIALS AND METHODS}

\section{Locality}

Řehačka alluvial lake $\left(50^{\circ} 10^{\prime} 39^{\prime \prime} \mathrm{N}, 14^{\circ} 48^{\prime} 27^{\prime \prime} \mathrm{E}\right)$ is situated close to the Elbe River. The lake covers 12.4 ha and represents an old oxbow of the River Elbe connected with an old flooded sand pit that is linked with the river by a pipeline connection. The water body is administered by the Czech Anglers Union, Local Organization Čelákovice, as a part of fishing district 'Labe $19 \mathrm{~A}^{\prime}$ and includes common fish stock. According to local fishing statistics and an ichthyological survey (T. Daněk unpubl. data), the fish stock consists of: Cyprinus carpio, Esox lucius, Sander lucioperca, Blicca bjoerkna, Tinca tinca, Anguilla anguilla, Silurus glanis, Abramis brama, Ctenopharyngodon idella, Aspius aspius, Perca fluviatilis, Gymnocephalus cernuus, Hypophthalmichthys molitrix, Hypophthalmichthys nobilis, Alburnus alburnus, Scardinius erythrophthalmus, Rutilus rutilus, Leuciscus idus, Rhodeus amarus, Ameiurus nebulosus and Carassius gibelio.

\section{Mortality evaluation}

Dead fish were collected from the lake by members of the local organization of the Czech Anglers Union, and quantities were recorded with information on water temperature. Additionally, a survey was conducted of representatives of other local organizations by the Czech Anglers Union along the Elbe River, and the authors of this study personally carried out inspections of localities reporting mass mortalities of Carassius gibelio.

\section{Fish identification and sex determination}

Moribund and dead fish were identified morphologically according to Kottelat \& Freyhof (2007) and additionally by sequencing of mitochondrial DNA of 8 specimens. The cytochrome $b$ gene was amplified by the methods described in Rylková et al. (2010), using forward primer Kai_F (GAA GAA CCA CCG TTG TTA TTC) and reverse primer Kai_R (ACC TCC RAY CTY CGG ATT ACA) (Šlechtová et al. 2006). PCR products were subsequently sequenced in both directions (Macrogen) and aligned. Sequences were compared with the Genetic sequence database (GenBank) at the National Center for Biotechnology Information (NCBI) using the basic local alignment search tool (BLASTn) program.

The sex of fish was determined by inspection of gonads at autopsy of 200 dead fish and in specimens used in ploidy level determination.

\section{Determination of ploidy level}

Thirty-two moribund Prussian carp were used for ploidy level determination. The ploidy level was determined by computer-assisted image analyses using the measurements of mean erythrocyte nuclei area (MENA) as was proposed by Flajšhans (1997). The blood was obtained with a heparinised syringe from the fish heart, and blood smears were prepared as for conventional haematological examination, then air-dried, fixed in $90 \%$ ethanol, and stained with $4 \%$ Giemsa-Romanowski. Blood smears were then processed on a system consisting of microscope 
(Nikon Eclipse 600, immersion objective 100x), analogue video camera (Hitachi HVC 20) and software (L.U.C.I.A version 4.71, Laboratory Imaging spol. sr. o.). The mean area of the nuclei was calculated from 200 erythrocytes for each specimen.

Moreover, the chromosome preparation according to Ráb \& Roth (1988) was performed on 3 of 32 diseased fish. Nuclear suspensions were dropped on slides, stained with $4 \%$ Giemsa-Romanovski, and examined microscopically. The chromosome counts were realized on the 10 best metaphase plates per specimen. The ploidy levels of 3 specimens obtained by chromosomes counts were used as a reference for the ploidy level determination by MENA and possible differences were tested by $t$-tests using the program Statistica version 9.1. (StatSoft).

\section{Identification of causative agent}

Five moribund fish originating from 3 separate samplings (sample no. 1736/1 contained 1 fish collected on 27 May 2011; sample no. 1736/2 contained 3 fish collected on 30 May 2011; sample no. 1736/3 contained 1 fish collected on 5 June 2011) were frozen $\left(-20^{\circ} \mathrm{C}\right)$ and transported to the laboratory. Standard pathological and parasitological examinations (Ergens \& Lom 1970) were carried out, and an ELISA test for spring viremia of carp virus (SVCV) formerly known as Rhabdovirus carpio (RVC) was undertaken (Test-Line). Virological examination consisted of isolation on tissue culture and identification of the pathogen by electron microscopy and PCR.

\section{Preparation of tissue homogenates}

Pooled fish tissues were homogenized in a mortar with sterile sea sand, supplemented with Eagle's medium Tris MEM (minimal essential medium, Sigma), pH 7.6, enriched with $10 \%$ FBS (foetal bovine serum, GIBCO) and centrifuged $\left(4^{\circ} \mathrm{C}, 1500 \times g\right.$, $15 \mathrm{~min})$. The supernatant was incubated overnight at $4^{\circ} \mathrm{C}$ with the addition of antibiotics $\left(100 \mathrm{IU} \mathrm{ml}^{-1}\right.$ of penicillin and $100 \mathrm{\mu g} \mathrm{ml}^{-1}$ of streptomycin) and afterwards used for cell line virological testing and for DNA extraction.

Isolation of viruses on tissue cultures

Monolayers (24 h) of bluegill fibroblast (BF-2), epithelioma papulosum cyprini (EPC), rainbow trout gonad (RTG-2) and fathead minnow (FHM) cell lines in 24-well plates (NUNC) were used for viral isolation. Cultures were inoculated with 3 serial tenfold dilutions of the examined samples and incubated at 15 and $23^{\circ} \mathrm{C}$ for $7 \mathrm{~d}$. The cell lines were monitored by microscope every day for the development of cytopathic effect (CPE). If no CPE was observed, the cultures were frozen, thawed and subcultured for an additional $7 \mathrm{~d}$. If CPE was not observed after the subculture, the samples were considered negative. Cell cultures exhibiting CPE were used for identification of viruses.

\section{Electron microscopy}

Supernatant from cell cultures displaying CPE were studied by electron microscopy. Subcultured samples were negatively stained with ammonium molybdate and examined using a Philips 208 transmission electron microscope (TEM) at $18000 \times$ magnification and an accelerating voltage of $90 \mathrm{kV}$.

\section{DNA extraction}

Tissue cultures with CPE were used for DNA isolation. The nucleic acid extraction was performed with a QIAamp DNA Mini kit (Qiagen) according to the manufacturer's instructions.

\section{PCR and sequencing}

Four primer pairs were used in this study; 2 pairs were used for a nested PCR on the thymidine kinase of CyHV-3 and 2 other pairs for a nested PCR on the DNA polymerase of cyprinid herpesviruses (Table 1). PCR products were subsequently sequenced in both directions using the ABI PRISM® BigDye® Terminator v3.1 Cycle Sequencing Kit (Applied Biosystems). Sequences were aligned using BioEdit version 5.0.9 and compared with GenBank using the BLASTn program.

\section{RESULTS}

\section{Mortality evaluation}

More than $1400 \mathrm{~kg}$ of dead fish were removed from Lake Řehačka within the period 22 May to 10 June 2011. On 22 May only $30 \mathrm{~kg}$ were collected, 
Table 1. Primer pairs used for identification of the virus. Nested PCRs targeted the thymidine kinase gene of herpesviral hematopoietic necrosis virus (CyHV-3) and the DNA polymerase gene of CyHV. One of 2 possible cycling conditions was used: (A) 40 cycles of $1 \mathrm{~min}$ at $95^{\circ} \mathrm{C}, 1 \mathrm{~min}$ at $55^{\circ} \mathrm{C}, 1 \mathrm{~min}$ at $72^{\circ} \mathrm{C}$, and the reaction was preceded by $94^{\circ} \mathrm{C}$ for $5 \mathrm{~min}$ and finished at $72^{\circ} \mathrm{C}$ for $10 \mathrm{~min}$, or (B) 30 cycles of $1 \mathrm{~min}$ at $95^{\circ} \mathrm{C}, 1 \mathrm{~min}$ at $55^{\circ} \mathrm{C}, 1 \mathrm{~min}$ at $72^{\circ} \mathrm{C}$, and the reaction was preceded by $94^{\circ} \mathrm{C}$ for $5 \mathrm{~min}$ and finished at $72^{\circ} \mathrm{C}$ for $10 \mathrm{~min}$. Centre for Environment, Fisheries \& Aquaculture Science (CEFAS) protocol can be obtained at www.cefas.defra.gov.uk

\begin{tabular}{|lccc|}
\hline Primer sequences $\left(5^{\prime}-3^{\prime}\right)$ & Cycle conditions & Size (bp) & Source \\
\hline CyHV-3 thimidine kinase & A & 409 & Bercovier et al. (2005) \\
Outer forward: GGG TTA CCT GTA CGA G & B & 348 & CEFAS protocol \\
$\begin{array}{l}\text { Outer reverse: CAC CCA GTA GAT TAT GC } \\
\text { Inner forward: CGT CTG GAG GAA TAC GAC G }\end{array}$ & & 362 & Jeffery et al. (2007) \\
Inner reverse: ACC GTA CAG CTC GTA CTG G & A & 339 & Jeffery et al. (2007) \\
$\begin{array}{l}\text { DNA polymerase gene of cyprinid herpesviruses } \\
\text { Outer forward: CCC AGC AAC ATG TGC GAC GG }\end{array}$ & B & & \\
$\begin{array}{l}\text { Outer reverse: CCG TAR TGA GAG TTG GCG CA } \\
\text { Inner forward: CGA CGG AGG CAT CAG CCC }\end{array}$ & & & \\
Inner reverse: GAG TTG GCG CAY ACY TTC ATC & & & \\
\hline
\end{tabular}

with the remaining fish collected on 27 May $(700 \mathrm{~kg})$, 30 May (300 kg), 1 June (300 kg), 5 June (100 kg), and the last dead specimens occurring on 10 June. Water temperature at the locality during this period was between 16.1 and $20.5^{\circ} \mathrm{C}$. To our knowledge, no other fish species were affected besides Carassius gibelio and no newly dead fish were observed after 10 June.

The survey among representatives of the local organization of the Czech Anglers Union also revealed the occurrence of a selective kill of Prussian carp in 4 other localities within the upper Elbe Basin (Fig. 1, numbers 2 to 5 ; Table 2).

\section{Identification and sex determination of fish from the Řehačka mortality event}

All 232 investigated fish (200 examined grossly and a further 32 for ploidy determination) were females and were morphologically identified as Carassius gibelio sensu Kottelat \& Freyhof (2007). Eight fish that were also investigated genetically shared 1 haplotype of Cyt $b \mathrm{mt}$ DNA (final length of sequences consisted of 1027 characters). Sequence of the haplotype was compared in the program BLASTn that evaluates the percentage of sequence similarity $(\% \mathrm{~S})$ and the percentage of sequence overlap (\%O) with the reference sequence of $C$. gibelio from GenBank (Table 3).

\section{Determination of ploidy level}

Chromosome preparation of 3 of the 8 specimens (Table 3) revealed they were triploids with modal chromosome numbers of 156 (60\% of investigated metaphases), 156 (50\% of investigated metaphases), and 150 (60\% of investigated metaphases). Ploidy level determination by MENA showed that all 32 investigated specimens were triploids with values of the nuclei area mean $( \pm \mathrm{SD})$ ranging from $20.7 \pm 2.2$

Table 2. Carassius gibelio. Selective mortalities of Prussian carp in the upper Elbe Basin. Biomass: biomass of dead fish, which were removed from the locality by local organisations of the Czech Anglers Union during 2011. See Fig. 1 for locations of localities. nd: no data

\begin{tabular}{|c|c|c|c|c|c|}
\hline $\begin{array}{l}\text { Locality } \\
\text { number }\end{array}$ & $\begin{array}{l}\text { Locality } \\
\text { name }\end{array}$ & Period & GPS position & $\begin{array}{l}\text { Biomass } \\
(\mathrm{kg})\end{array}$ & $\%$ mortality \\
\hline 1 & Řehačka & 22 May-10 June & $50^{\circ} 10^{\prime} 37.956^{\prime \prime} \mathrm{N}, 14^{\circ} 48^{\prime} 22.419^{\prime \prime} \mathrm{E}$ & $>1400$ & $>95$ \\
\hline 2 & Pňov & 30 June-5 July & $50^{\circ} 5^{\prime} 36.024^{\prime \prime} \mathrm{N}, 15^{\circ} 9^{\prime} 11.413^{\prime \prime} \mathrm{E}$ & $>700$ & nd \\
\hline 3 & Nová Ves & 30 June-25 July & $50^{\circ} 3^{\prime} 24.666^{\prime \prime} \mathrm{N}, 15^{\circ} 9^{\prime} 35.738^{\prime \prime} \mathrm{E}$ & $>5600$ & $>95$ \\
\hline 4 & Trnávka & 1 June-11 June & $50^{\circ} 1^{\prime} 56.253^{\prime \prime} \mathrm{N}, 15^{\circ} 27^{\prime} 48.229^{\prime \prime} \mathrm{E}$ & 150 & nd \\
\hline 5 & Hrobice & 5 June-19 June & $50^{\circ} 6^{\prime} 28.754^{\prime \prime} \mathrm{N}, 15^{\circ} 47^{\prime} 23.408^{\prime \prime} \mathrm{E}$ & 100 & nd \\
\hline
\end{tabular}




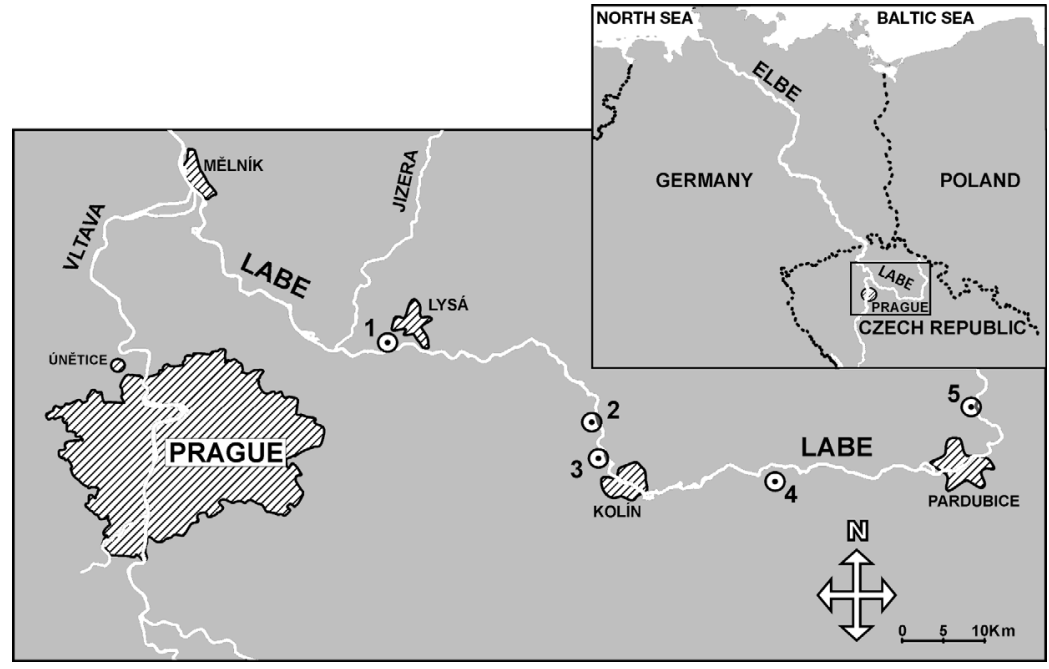

Fig. 1. Localities with selective Prussian carp Carassius gibelio mortalities. Cases (numbers 1 to 5 in main map) are described in Table 2

Table 3. Carassius gibelio. Genetic and cytogenetic identification of 8 specimens of Prussian carp from Lake Řehačka (CgTL006, CgTL008, CgTL013, CgTL046, CgTL078, CgTL114, CgTL144 and CgTL113). Basic local alignment seach tool (BLASTn) comparisons used reference sequence from Carassius gibelio DQ399929 (Kalous et al. 2007). \%S: percentage of overlap sequence similarity; \%O: percentage of sequence overlap; MENA: mean erythrocyte nuclei area; Chro: modal chromosome number

\begin{tabular}{|c|c|c|c|c|c|c|}
\hline \multirow[t]{2}{*}{ Specimen } & \multirow{2}{*}{$\begin{array}{l}\text { Morphological } \\
\text { identification }\end{array}$} & \multicolumn{2}{|c|}{ Ploidy level } & \multirow{2}{*}{$\begin{array}{c}\text { GenBank } \\
\text { Accession No. }\end{array}$} & \multirow[t]{2}{*}{$\% \mathrm{~S}$} & \multirow[t]{2}{*}{$\% \mathrm{O}$} \\
\hline & & MENA & Chro & & & \\
\hline CgTL006 & Carassius gibelio & $3 n$ & 156 & JN546055 & 100 & 98 \\
\hline CgTL008 & Carassius gibelio & $3 n$ & 156 & JN546056 & 100 & 98 \\
\hline CgTL013 & Carassius gibelio & $3 n$ & 150 & JN546057 & 100 & 98 \\
\hline CgTL046 & Carassius gibelio & $3 n$ & - & JN546058 & 100 & 98 \\
\hline CgTL078 & Carassius gibelio & $3 n$ & - & JN546043 & 100 & 98 \\
\hline CgTL114 & Carassius gibelio & $3 n$ & - & JN546041 & 100 & 98 \\
\hline CgTL144 & Carassius gibelio & $3 n$ & - & JN546040 & 100 & 98 \\
\hline CgTL113 & Carassius gibelio & $3 n$ & - & JN546034 & 100 & 98 \\
\hline
\end{tabular}

to $23.2 \pm 2.5 \mu^{2}$. Comparison of values using a $t$-test confirmed no statistically significant difference $(\mathrm{p}>$ 0.05) between the 3 reference specimens and the remaining specimens (Fig. 2). All values are in agreement with those for triploid Carassius gibelio (Kalous \& Petrtýl 2004).

\section{Identification of causative agent of mortality}

Diseased Prussian carp had pinpoint red foci at the base of their fins, red foci in the eyes, haemorrhaging of the gills, and some specimens showed pink-colored skin in the abdominal region and fins (Fig. 3). Internal organs were soft and reddened. Standard pathological and parasitological examina- tion failed to detect parasites or evidence of spring viremia of carp. Given that the massive mortality was selective for Carassius gibelio, toxicosis was also excluded.

\section{Isolation of viruses on tissue cultures and electron microscopy}

Three separate fish samples (1736/ 1, 1736/2 and 1736/3) produced CPE on first passage in all 4 cell lines incubated at $23^{\circ} \mathrm{C}$ and in BF-2, FHM and RTG 2 cell lines incubated at $15^{\circ} \mathrm{C}$. Cell cultures with clear CPE were examined by TEM, and viral particles morphologically similar to a herpesvirus were observed (Fig. 4). These samples were tested by PCR.

\section{PCR and sequencing}

Samples with CPE and herpesviral particles observed in TEM were investigated by nested PCR using primers specific for koi herpesvirus (CyHV-3) (Table 1). Negative results were obtained. Subsequently generic primers for the DNA polymerase gene of cyprinid herpesviruses were used (Table 1) and a primary product of $362 \mathrm{bp}$ was obtained in 2 of 3 separate samples. The nested PCR resulted in a specific product of $339 \mathrm{bp}$ in all 3 samples (Fig. 5). Products were sequenced and the sequences were deposited in GenBank (accession nos. JQ740764, JQ740765 and JQ740766). Nucleotide sequences were compared with GenBank using the BLASTn program and exhibited $100 \%$ identity with cyprinid herpesvirus 2 DNA polymerase gene (GenBank accession no. DQ085628.1) (Goodwin et al. 2006a).

\section{DISCUSSION}

The causative agent of a massive kill of Prussian carp was identified as CyHV-2, family Alloherpesviridae, genus Cyprinivirus (Davison et al. 2009). This virus shares morphological similarities with carp pox herpesvirus (CyHV-1) and koi herpesvirus 


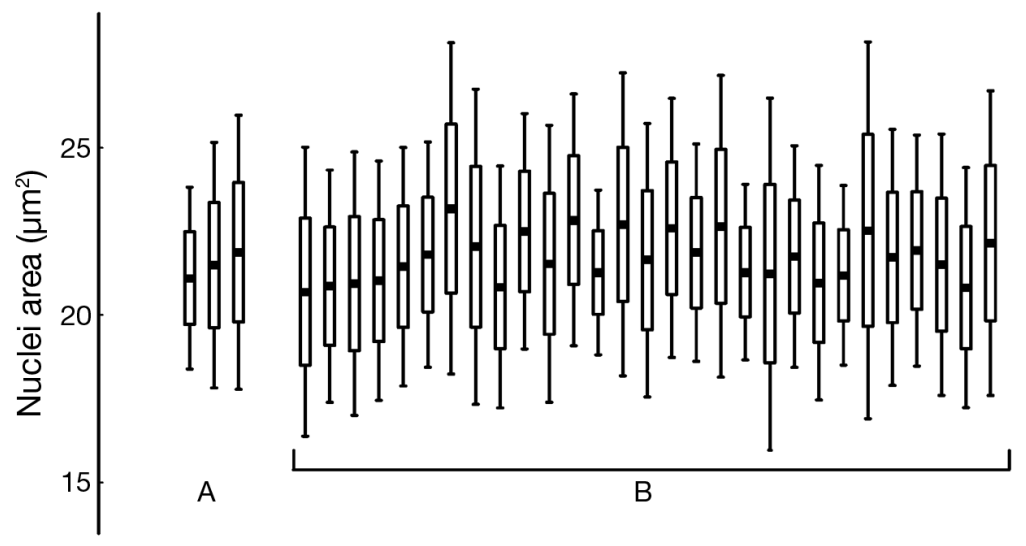

Fig. 2. Carassius gibelio. Obtained erythrocyte nuclei area of triploid reference specimens (A) and the remaining 29 specimens (B) from Lake Rehačka. Thick black line: mean; box: SD; whiskers: $1.96 \times \mathrm{SD}$
(CyHV-3), but it differs in the clinical manifestation, host range, antigenic properties, and growth characteristics (Waltzek et al. 2005). (CyHV-2) is a pathogen of goldfish Carassius auratus (Goodwin et al. 2006b, Jeffery et al. 2007), but recently it was also identified in C. gibelio in Hungary (Doszpoly et al. 2011). In the case of Lake Rehačka, all affected fish were C. gibelio. CyHV-2 is associated with mortality in at least 2 species of the genus $\mathrm{Ca}$ rassius - C. auratus and C. gibeliobut it seems not to be pathogenic for C. carassius (Jeffery et al. 2006) or for common carp Cyprinus carpio (Jung \& Miyazaki 1995).

CyHV-2 was originally described in Japan (Jung \& Miyazaki 1995) but it probably has a global distribution (Waltzek et al. 2009), with mortality reported in the United Kingdom (Jeffery et al. 2007), USA, Taiwan (Goodwin et al. 2006a) and Australia (Stephens et al. 2004).

The high mortality within goldfish can be attributed to their low genetic diversity (Rylková et al. 2010) since this species has experienced intensive selection during its breeding history (Balon 2004). We presume that some of the differences in the manifestation of the disease at Lake Rehačka in comparison to previously described symptoms (Jung \& Miyazaki 1995, Stephens et al. 2004, Jeffery et al. 2007) could be influenced by the heterogeneity of affected species within the genus Carassius.
Fig. 3. Carassius gibelio. Freshly dead fish from Lake Řehačka affected by CyHV-2 showing pinpoint foci at the base of fins and in the eyes

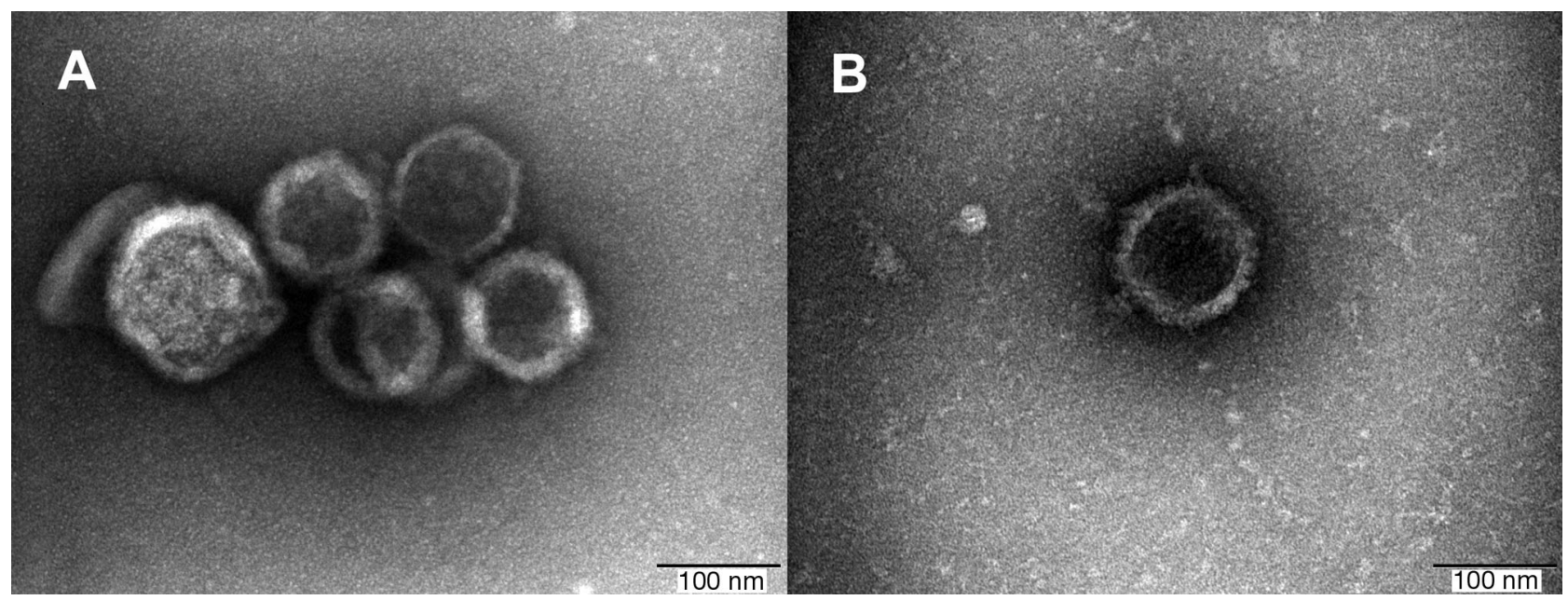

Fig. 4. Viral particles with a herpesviral morphology isolated in different cell lines and temperatures. (A) Rainbow trout gonad cell line, $15^{\circ} \mathrm{C}$. (B) Epithelioma papulosum cyprini cell line, $23^{\circ} \mathrm{C}$. Transmission electron microscopy; negative staining 


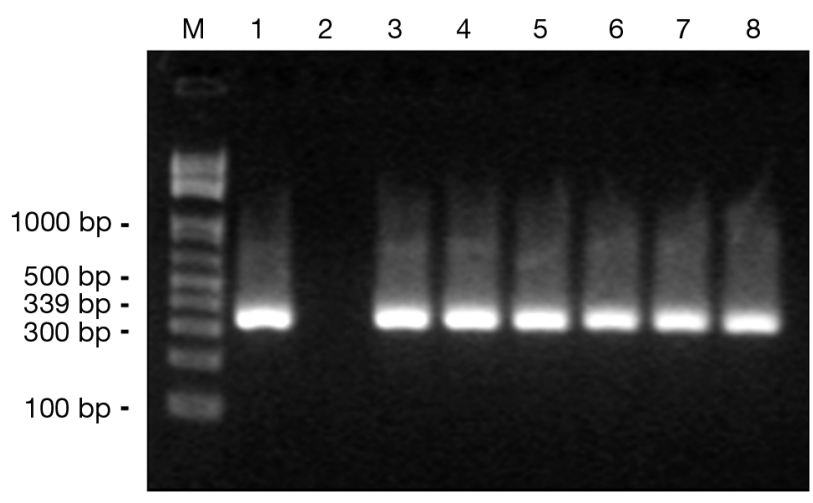

Fig. 5. Nested generic PCR of the DNA polymerase gene of CyHV. Lane M: mass ladder (TrackIt $1 \mathrm{~Kb}$ Plus DNA Ladder, Invitrogen); Lane 1: positive control; Lane 2: negative control; Lane 3: Sample 1736/1; Lane 4: Sample 1736/2; Lane 5: Sample 1736/3; Lanes 6 to 8: Same samples after virus multiplication in cell line RTG-2, $23^{\circ} \mathrm{C}$

The natural populations of Carassius gibelio consist of clonal lineages with the sympatric occurrence of sexually reproducing individuals (Gui \& Zhou 2010). In contrast, in newly inhabited areas the populations are characterized by the dominance of females that take advantage of rapid multiplication due to sperm-dependent parthenogenetic reproduction (Hänfling 2007). Our data suggest that the C. gibelio population from Lake Řehačka is gynogenetic since not a single male was found. Moreover, all investigated specimens were shown to be triploids, and only 1 haplotype of Cyt $b$ mtDNA was shared among 8 sequenced fish.

Populations of asexually reproducing vertebrates are often considered to be less resistant to pathogens due to reduced genetic variability of the host (Neiman \& Koskella 2009). In natural populations that reproduce sexually, usually only a fraction of individuals infected by viruses show symptoms of disease, and a significant part of the clinical variability observed within populations is explained by the host genetic background that plays an important role in the susceptibility to infections (Verrier et al. 2012). This phenomenon changes in a genetically uniform population caused by artificial selection. Within the common carp Cyprinus carpio, strains more or less susceptible to CyHV-3 have been identified (Shapira et al. 2005, Ødegård et al. 2010). High stock densities and low genetic variability can result in mass mortalities from virus, e.g. in koi carp (Hedrick at al. 2000), or even in introduced common carp in a natural environment (Garver et al. 2010). Animals that reproduce clonally face the same pop- ulation breakdown possibility when infected by highly pathogenic viruses due to their obvious genetic similarity. Although we did not completely define the genotype diversity of Prussian carp in Lake Řehačka, only a few clonal lineages are likely to be present due to the bottle-neck effect associated with introduction and the gynogenetic type of reproduction. Our cytogenetic data showed 2 different modal chromosome numbers. The triploid biotype of Carassius gibelio is known to bear various numbers of chromosomes from 150 to 162 (Kalous \& Knytl 2011). Particular clones are then usually characterized by a specific chromosome number (Zhou \& Gui 2002). In the case of Lake Řehačka, there are at least 2 clones, although the cytogenetic data in the study are very restricted.

After the first dead fish appeared on 22 May, numbers rapidly increased within $5 \mathrm{~d}$. One week after the peak of mortality, only a few newly dead specimens were found. Estimating mortality in natural waterbodies is very difficult. However, based on information from the local organization of the Czech Anglers Union and the complete lack of Prussian carp caught at the locality by anglers in the period 10 June 2011 to July 2012, we assume that all or nearly all of the Carassius gibelio in Lake Řehačka were eliminated by the pathogen during this short period.

The rapid progress of the pathogen was also reported in controlled conditions when fish began to die at 3 to $6 \mathrm{~d}$ post-inoculation and cumulative mortality ranged from 60 to $100 \%$, depending on viral titre, within $13 \mathrm{~d}$ at $20^{\circ} \mathrm{C}$ (Jung \& Miyazaki 1995). CyHV-2 is often present as an inapparent infection and could be widespread in nature (Goodwin et al. 2009). However, when infected fish are subjected to stress such as a temperature change, there is a greater probability of disease outbreaks.

We believe the stress/temperature hypothesis may explain the initiation of the disease outbreak at Lake Řehačka and other locations in the upper Elbe River because a sharp drop in water temperature occurred from 13 May to 16 May 2011. Additionally our data showed that the virus replicated well in the temperature range 15 to $23^{\circ} \mathrm{C}$, which is in agreement with Jung \& Miyazaki (1995) who noted the optimum for virus propagation ranging between 15 and $25^{\circ} \mathrm{C}$.

We conclude that the massive wave of deaths of Prussian carp at Lake Řehačka and at other localities in the upper Elbe River basin can be attributed to limited genetic variation of Prussian carp and the favourable conditions for propagation of CyHV-2. 
Acknowledgements. The authors thank the representatives of the local organizations of the Czech Anglers Union for their assistance during fieldwork (especially P. Jindřich from the Local Organization Čelákovice). Additionally we are grateful to the anonymous referees for their valuable suggestions. This work was financially supported by MZE0002716202 from the Ministry of Agriculture of the Czech Republic and TAČR TD010045 from the Technology Agency of the Czech Republic.

\section{LITERATURE CITED}

Abramenko MI, Poltavtseva TG, Vasetskii SG (1998) Discovery of triploid males in lower Don populations of the crucian carp Carassius auratus gibelio (Bloch, 1782). Dokl Akad Nauk 363:415-418 (in Russian)

Abramenko MI, Nadtoka EV, Makhotkin MA, Kravchenko OV, Poltavtseva TG (2004) Distribution and cytogenetic features of triploid males of crucian carp in Azov Basin. Russ J Dev Biol 35:305-315

Balon EK (2004) About the oldest domesticates among fishes. J Fish Biol 65(Suppl 1):1-27

Bercovier H, Fishman Y, Nahary R, Sinai S and others (2005) Cloning of the koi herpesvirus (KHV) gene encoding thymidine kinase and its use for a highly sensitive PCR based diagnosis. BMC Microbiol 5:13

Černý J, Sommer N (1992) Vek, rast a produkcia karasa striebristého Carassius auratus v ramene Dunaja r. km. 1825 v r. 1985-1990. Sborník z konferencie ichtyologickej sekcie. SZS, Bratislava, p 46-58

Davison AJ, Eberle R, Ehlers B, Hayward GS and others (2009) The order Herpesvirales. Arch Virol 154:171-177

Doszpoly A, Benk M, Csaba G, Dán Á, Láng M, Harrach B (2011) Introduction of the family Alloherpesviridae: the first molecular detection of herpesviruses of cyprinid fish in Hungary. Magyar Allatorvosok Lapaja 133:174-181

Economidis PS, Dimitriou E, Pagoni R, Michaloudi E, Natsis L (2000) Introduced and translocated fish species in the inland waters of Greece. Fish Manag Ecol 7:239-250

Ergens R, Lom J (1970) Causative agents of parasitic fish diseases. Academia, Prague (in Czech)

Flajšhans M (1997) A model approach to distinguish diploid and triploid fish by means of computer-assisted image analysis. Acta Vet 66:101-110

Garver KA, Al-Hussinee L, Hawley LM, Schroeder T and others (2010) Mass mortality associated with koi herpesvirus in wild common carp in Canada. J Wildl Dis 46: 1242-1251

> Goodwin AE, Khoo L, LaPatra SE, Bonar C and others (2006a) Goldfish hematopoietic necrosis herpesvirus (cyprinid herpesvirus 2) in the USA: molecular confirmation of isolates from diseased fish. J Aquat Anim Health 18:11-18

$>$ Goodwin AE, Merry GE, Sadler J (2006b) Detection of the herpesviral hematopoietic necrosis disease agent (Cyprinid herpesvirus 2) in moribund and healthy goldfish: validation of a quantitative PCR diagnostic method. Dis Aquat Org 69:137-143

> Goodwin AE, Sadler J, Merry GE, Marecaux EN (2009) Herpesviral haematopoietic necrosis virus (CyHV-2) infection: case studies from commercial goldfish farms. J Fish Dis 32:271-278

Gui JF, Zhou L (2010) Genetic basis and breeding applica- tion of clonal diversity and dual reproduction modes in polyploid Carassius auratus gibelio. Sci China Life Sci 53:409-415

Hakoyama H, Nishimura T, Matsubara N, Iguchi K (2001) Difference in parasite load and nonspecific immune reaction between sexual and gynogenetic forms of Carassius auratus. Biol J Linn Soc 72:401-407

Halačka K, Lusková V, Lusk S (2003) Carassius gibelio in fish communities of the Czech Republic. Ecohydrol Hydrobiol 3:133-138

Hänfling B (2007) Understanding the establishment success of non-indigenous fishes: lessons from population genetics. J Fish Biol 71:115-135

Hedrick RP, Gilad O, Yun S, Spangenberg JV and others (2000) A herpesvirus associated with mass mortality of juvenile and adult koi, a strain of common carp. J Aquat Anim Health 12:44-57

Holčík J, Žitňan R (1978) On the expansion and origin of Carassius auratus in Czechoslovakia. Folia Zool 27: 279-288

Jeffery KR, Hulland J, Longshaw CB, Bateman K and others (2006) (poster) Emergence of a cyprinid herpesvirus (CyHV-2) in goldfish Carassius auratus in the UK. Inst Fish Manag (IFM) Annu Conf, 7 Nov 2006. CEFAS, Lowestoft

Jeffery KR, Bateman K, Bayley A, Feist SW and others (2007) Isolation of a cyprinid herpesvirus (CyHV-2) from goldfish Carassius auratus (L.), in the UK. J Fish Dis 30: 649-656

Jung SJ, Miyazaki T (1995) Herpesviral haematopoietic necrosis of goldfish, Carassius auratus (L.). J Fish Dis 18: 211-220

Kalous L, Knytl M (2011) Karyotype diversity of the offspring resulting from reproduction experiment between diploid male and triploid female of silver Prussian carp, Carassius gibelio (Cyprinidae, Actinopterygii). Folia Zool 60: 115-121

Kalous L, Petrtýl M (2004) Contribution to the ploidy of silver Prussian carp (Carassius gibelio). Proc VII Czech Ichthyol Conf, p 64-68 (in Czech)

Kalous L, Šlechtová V Jr, Bohlen J, Petrtýl M, Švátora M (2007) First European record of Carassius langsdorfii from the Elbe basin. J Fish Biol 70:132-138

Kottelat M, Freyhof J (2007) Handbook of European freshwater fishes. Publications Kottelat, Cornol

Kubečka J (1989) Šíření karasa stříbřitého, Carassius auratus (Linaeus, 1758) ve středním Polabí. Muzeum a sou asnost, Roztoky, ser. Natur 3:43-50

Lamatsch DK, Stöck M (2009) Sperm-dependent parthenogenesis and hybridogenesis in teleost fishes. In: Schön I, Martens K, van Dijk P (eds) Lost sex: the evolutionary biology of parthenogenesis. Springer, Dordrecht, p 399-432

Lively CM, Craddock C, Vrijenhoek RC (1990) Red Queen hypothesis supported by parasitism in sexual and clonal fish. Nature 344:864-866

Lusk S (1986) The areas of occurrence of giebel carp (Carassius auratus) under Czechoslovak conditions. Živočišná výroba 31:945-951

Lusk S, Baruš V, Veselý V (1977) On the question of the occurrence of Carassius auratus L. in the Morava River watershed. Folia Zool 26:377-381

Lusk S, Baruš V, Kirka A (1980) Current spreading and importance of the Gibel (Carassius auratus gibelio Bloch) in Czechoslovakia. Živočišná výroba 25:871-878 
Lusk S, Lusková V, Halačka K (1998) Karas stříbřitý — 25 let od jeho přirozené introdukce. [Prussian carp - 25 years since its natural introduction]. Proc III Czech Ichthyol Conf, 6-7 May 1998. VURH, Vodňany, p 135-140 (in Czech)

Lusková V, Halačka K, Vetešník L, Lusk S (2004) Changes of ploidy and sexuality status of Carassius auratus populations in the drainage area of the River Dyje (Czech Republic). Ecohydrol Hydrobiol 4:165-171

Lusková V, Lusk S, Hala ka K, Vetešník L (2010) Carassius auratus gibelio - the most successful invasive fish in waters of the Czech Republic. Russ J Biol Invasions 2:24-28

Moritz C, Mccallum H, Donnellan S, Roberts JD (1991) Parasite loads in parthenogenetic and sexual lizards (Heteronotia binoei): support for the Red Queen hypothesis. Proc R Soc Lond B Biol Sci 244:145-149

Neiman M, Koskella B (2009) Sex and the Red Queen. In: Schön I, Martens K, van Dijk P (eds) Lost sex: the evolutionary biology of parthenogenesis. Springer, Dordrecht, p 133-159

Ødegård J, Olesen I, Dixon P, Zsigmond J and others (2010) Genetic analysis of common carp (Cyprinus carpio) strains. II: Resistance to koi herpesvirus and Aeromonas hydrophila and their relationship with pond survival. Aquaculture 304:7-13

Özcan G (2007) Distribution of non-indigenous fish species, Prussian carp Carassius gibelio (Bloch, 1782) in the Turkish freshwater systems. Pak J Biol Sci 10:4241-4245

Peňáz M, Ráb P, Prokeš M (1979) Cytological analysis, gynogenesis and early development of Carassius auratus gibelio. Acta Sci Naturalis 13:1-33

> Poulin R, Marshall LJ, Spencer HG (2000) Metazoan parasite species richness and genetic variation among freshwater fish species: cause or consequence? Int J Parasitol 30:697-703

Ráb P, Roth P (1988) Cold-blooded vertebrates. In: Balíček P, Forejt J, Rubeš J (eds) Methods of chromosome analysis. Cytogenetická sekce Československé biologické společnosti při ČSAV, Brno, p 115-124

Rylková K, Kalous L, Šlechtová V, Bohlen J (2010) Many branches, one root: first evidence for a monophyly of the morphologically highly diverse goldfish (Carassius auratus). Aquaculture 302:36-41

Savini D, Occhipinti-Ambrogi A, Marchini A, Tricarico E, Gherardi F, Olenin S, Gollasch S (2010) The top 27 animal alien species introduced into Europe for aquaculture and related activities. J Appl Ichthyology 26:1-7
Shapira Y, Magen Y, Zak T, Kotler M, Hulata G, LevaviSivan B (2005) Differential resistance to koi herpes virus (KHV)/carp interstitial nephritis and gill necrosis virus (CNGV) among common carp (Cyprinus carpio L.) strains and crossbreds. Aquaculture 245:1-11

Slavík O, Bartoš L (2004) What are the reasons for the Prussian carp expansion in the upper Elbe River, Czech Republic? J Fish Biol 65(Suppl A):240-253

Šlechtová V, Bohlen J, Freyhof J, Ráb P (2006) Molecular phylogeny of the Southeast Asian freshwater fish family Botiidae (Teleostei: Cobitoidea) and the origin of polyploidy in their evolution. Mol Phylogenet Evol 39: 529-541

Somamoto T, Okamoto N, Nakanishi T, Ototake M, Nakao $M$ (2009) In vitro generation of viral-antigen dependent cytotoxic T-cells from ginbuna crucian carp, Carassius auratus langsdorfii. Virology 389:26-33

> Stephens FJ, Raidal SR, Jones B (2004) Haematopoietic necrosis in a goldfish (Carassius auratus) associated with an agent morphologically similar to herpesvirus. Aust Vet J 82:167-169

Tóth B, Várkonyi E, Hidas A, Edviné Meleg E, Váradi L (2005) Genetic analysis of offspring from intra- and interspecific crosses of Carassius auratus gibelio by chromosome and RAPD analysis. J Fish Biol 66:784-797

Varadi L, Harka A, Sallai Z, Jozsa V, Toth B (2000) The silver crucian carp (Carassius auratus gibelio Bloch, 1863) in Hungary. Fish Dev Hungary 24:71-81

Verrier ER, Langevin C, Tohry C, Houel A and others (2012) Genetic resistance to rhabdovirus infection in teleost fish is paralleled to the derived cell resistance status. PLoS ONE 7:e33935

Vetešník L (2005) Biological characteristic of silver prussian carp (Carassius auratus) under the aspect of different ploidy level between individuals. PhD thesis, Mendel University in Brno

Waltzek TB, Kelley GO, Stone DM, Way K, and others (2005) Koi herpesvirus represents a third cyprinid herpesvirus (CyHV-3) in the family Herpesviridae. J Gen Virol 86: 1659-1667

Waltzek TB, Kurobe T, Goodwin AE, Hedrick RP (2009) Development of a polymerase chain reaction assay to detect cyprinid herpesvirus 2 in goldfish. J Aquat Anim Health 21:60-67

Z Zhou L, Gui JF (2002) Karyotypic diversity in polyploid gibel carp, Carassius auratus gibelio Bloch. Genetica 115: 223-232

Submitted: June 25, 2012; Accepted: September 17, 2012

Proofs received from author(s): December 3, 2012
Editorial responsibility: Mark Crane,

Geelong, Victoria, Australia 